Article

\title{
Reconnecting Amphibian Habitat through Small Pond Construction and Enhancement, South Okanagan River Valley, British Columbia, Canada
}

\author{
Sara L. Ashpole ${ }^{1, * \mathbb{D}}$, Christine A. Bishop ${ }^{2}$ and Stephen D. Murphy ${ }^{3}$ \\ 1 Environmental Studies, St. Lawrence University, Canton, NY 13617, USA \\ 2 Environment and Climate Change Canada, Delta, BC V4K 3N2, Canada; cab.bishop@canada.ca \\ 3 School of Environment, Resources \& Sustainability, University of Waterloo, Waterloo, ON N2L 3G1, Canada; \\ stephen.murphy@uwaterloo.ca \\ * Correspondence: sashpole@stlawu.edu
}

Received: 31 May 2018; Accepted: 7 September 2018; Published: 29 September 2018

\begin{abstract}
The arid south Okanagan River Valley, British Columbia is a highly-modified landscape; where wetland and riparian habitat loss exceeds $85 \%$, and $88 \%$ of remaining wetlands experience at least one harmful anthropogenic stressor. This multi-stressor landscape for amphibian species at risk led to a collaborative stakeholder approach for habitat restoration and species recovery. The main project goal was to increase the quantity and quality of lowland wetland habitat by reconnecting known amphibian-breeding sites with constructed and/or enhanced small ponds. Long-term amphibian monitoring data were used to determine strategic locations for wetland construction and/or enhancement. Habitat enhancement outcomes ( $N_{\text {total }}=21$ sites) since 2006 include 10 newly constructed ponds, enhancement of eight re-contoured ponds after historic infilling, and invasive predatory species removal at three sites. Project ponds were monitored annually (2007 to 2014) for calling frogs, the presence of eggs, and metamorphic emergence. Early signs of colonization and metamorphic success for Great Basin Spadefoot (Spea intermontana) $(N=13$ sites) and Pacific treefrog (Pseudacris regilla) ( $N=7$ sites) populations have been observed, however no records of Blotched tiger salamanders (Ambystoma mavortium) colonization has been detected. Wetland habitat construction and enhancement have doubled the number of available fishless ponds to support breeding within the study area and engaged landowners through voluntary stewardship. Whether constructed or enhanced ponds have aided species recovery is unclear, though the colonization and successful metamorphosis of some species provides early supporting evidence that it will.
\end{abstract}

Keywords: agroecosystems; amphibian; ecological planning; terrestrial habitat; wetland restoration

\section{Introduction}

It has been estimated that, $32.4 \%$ of amphibian populations are globally threatened (IUCN categories; [1]) implying a rate of mass extinction [2]. Habitat loss is considered the most significant factor in this decline; other stressors such as pollution, overexploitation, non-native species, and disease are also contributing factors (see [3]). To counteract these problems, a variety of approaches have been used including translocation and habitat restoration [4-6]. In each of these initiatives, the lack of quantification of success or failure of these techniques has often made it difficult to determine if they have made any long-term difference to amphibian populations on a local or broader scale. In Canada, amphibians experience the same stressors as elsewhere along with a shorter growing season and extreme winter temperatures [7]. Even with the highest annual average temperatures in Canada [8], in the south Okanagan River Valley, British Columbia, the long-term survival of amphibian populations 
is uncertain in the lowland valley (see [9] for map of this area) Status reports on amphibians at risk in the Okanagan River Valley note the impact of habitat loss [10,11]. These amphibian species are relying on less than $16 \%$ of the historic wetlands [12] yet there is recognition that the remaining wetland ecosystem supports unique desert adapted amphibian diversity [13].

Within the south Okanagan River Valley, British Columbia, low species richness ( $66 \%$ of sites $<2$ species) and very low reproductive success in the remaining ponds in this region ( $67 \%$ of sites $<10$ individuals of any early life stage), suggests that survival of populations may require intervention. While natural ponds are scarce, agricultural ponds in the lower Valley now represent an alternative and perhaps prevalent breeding habitat [9] and likely contribute significantly to amphibian population persistence [14]. The creation of small ponds that are near to one another and interconnected by relatively natural corridors may be an approach that could support recovery of distinct populations of amphibian species at risk occurring in the south Okanagan River Valley. The south Okanagan River Valley landscape fits within the theoretical principles of Island Biogeography Theory [15], 'Single Large Or/And Several Small' (SLOSS/SLASS) protected area management [16], and the dynamics of Metapopulation Theory [17]. However, the value of artificial construction of wetlands to mitigate losses for amphibians can be successful or, in some cases, ambiguous [4,18]. While it is suggested that surrounding habitat features might not influence pond species diversity [14], terrestrial habitat and surrounding pond clusters have been landscape indicators in some species occurrence [19]. Perhaps more important, is species specific habitat preference, dispersal ability (see review [20]), and shallows for breeding [21]. Similarly, spatial orientation has been associated with colonization and richness [22] along with accessibility to nearby fishless aquatic habitat with minimal anthropogenic disturbance [6]. The association of predatory fish with reduced species richness [21] and amphibian avoidance of habitats, that may drive patchy configuration (vs. metapopulations) [23] is well acknowledged in the literature. Constructing ponds to support predator free environments are critical in regions, like ours, where historic native aquatic predators are few in pond mosaics but predator introductions are pervasive; such sites might act as sinks or ecological traps luring species into poor quality habitat.

Our long-term goal is to produce a complex of wetlands where amphibian communities are similar to, or increasing in population size, compared to existing south Okanagan River Valley ponds [9]. After constructing and enhancing 21 ponds within the south Okanagan River Valley we tested several hypotheses to determine whether these ponds attracted amphibians, and if they could successfully reproduce in these ponds. We propose a hypothesis to explain the use of constructed and enhanced wetlands as a recovery action to support amphibian species at risk. If amphibians can use anthropomorphic breeding sites, then the construction of strategically placed ponds within the dispersal ability of species will increase the number of potential breeding sites and consequently this utilization will result in successful reproduction and serve to increase breeding habitat. We also examined whether terrestrial soil habitat characteristics that are required by fossorial species surrounding constructed or enhanced ponds were similar or different than existing ponds.

\section{Methods}

\subsection{Site Selection}

Sites for wetland pond construction, enhancement, and/or non-native invasive species removal were selected based on known herpetofaunal species data, biological criteria (e.g., dispersal abilities, see $[24,25])$. We also used historical wetland occurrence records, or where a partnership with a non-government organizations, government organizations and conservation authorities existed (i.e., wetland mitigation compensation British Columbia Ministry of Transportation and Infrastructure). The partnership arrangements required landowners to sign a five to ten-year voluntary stewardship agreement that outlined permissible (e.g., installation of bat boxes) or restricted activities (e.g., addition of non-native plant or animal species) around the pond. 
Ideally, the biological and management criteria for choosing sites for wetlands activities are within the $500 \mathrm{~m}$ critical core habitat representing the terrestrial area required by the species to sustain life history requirements [26,27]. Therefore, areas within $500 \mathrm{~m}$ of a known target species breeding population [9] were preferred (Figure 1). To support connectivity movement between wetland features and breeding sites, we target areas within $500 \mathrm{~m}$ of an additional water way (pond, lake, creek, oxbow). While the nature of the road network within a restrictive topography present a significant threat to species [28], we set a criterion of a minimum $100 \mathrm{~m}$ distance from a roadway.

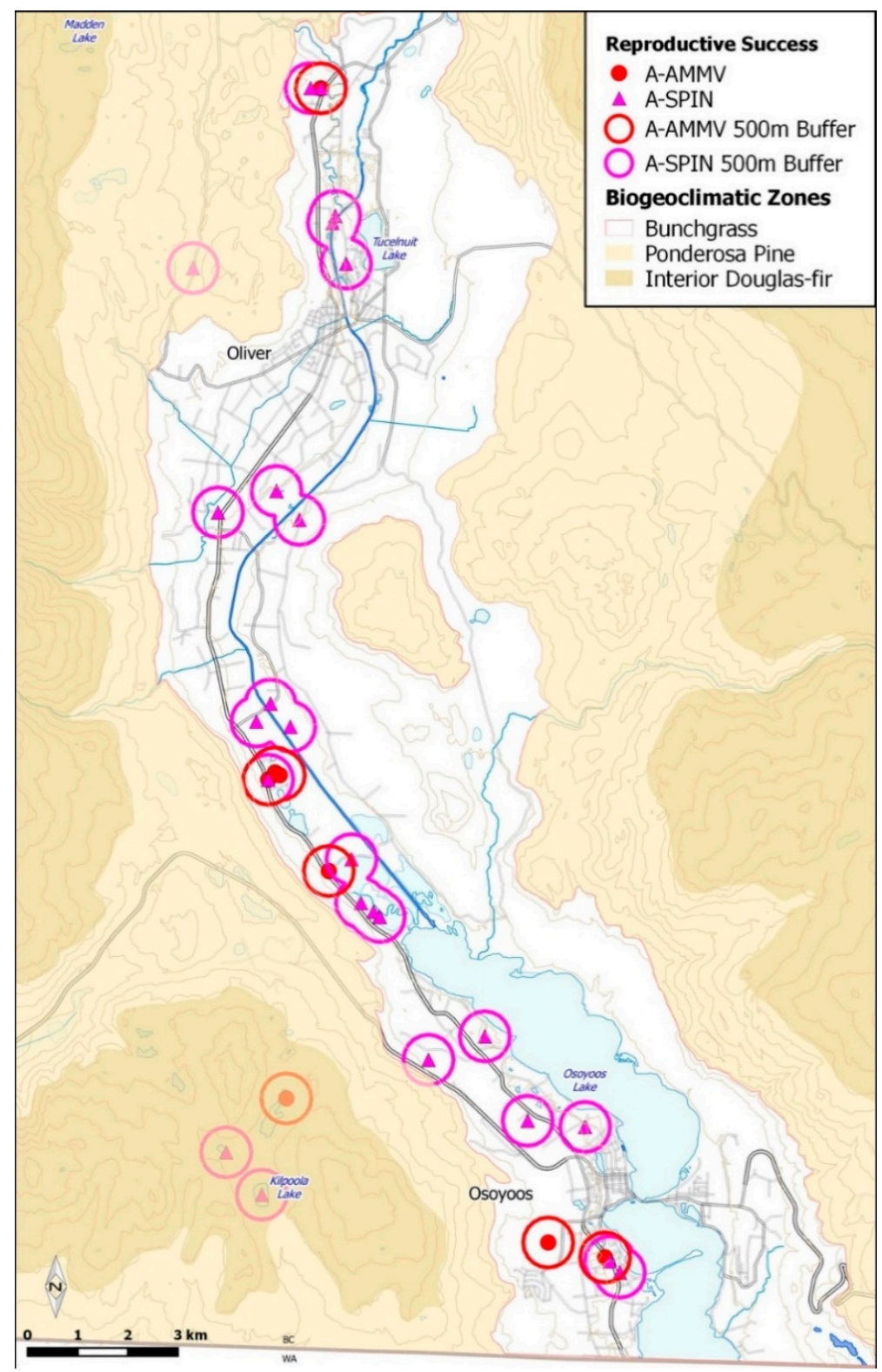

Figure 1. Biological criteria used for informing wetland enhancement and restoration activities within the south River Okanagan Valley, British Columbia study area [9]. Breeding success of known Great Basin spadefoot (pink triangle) and Blotched tiger salamander (red circle) was presumed by the presence of early life stages (e.g., eggs, tadpole/larvae, metamorph). To increase the likelihood of constructed and enhanced wetland colonization, a $500 \mathrm{~m}$ buffer around the known Great Basin spadefoot (pink perimeter) and Blotched tiger salamander (red perimeter) breeding sites was used to help prioritize wetland habitat activities. Amphibian (A) species codes: A-AMMV Blotched tiger salamander, A-SPIN Great Basin spadefoot. Biogeoclamatic zones include Bunchgrass, Ponderosa Pine (Pinus ponderosa), and Douglas-fir (Pseudotsuga menziesii). 


\subsection{Pond Habitat Construction and Enhancement}

Pond habitat activities were classified into one of three classes (Table 1):

1. Construction $(N=10)$ : No pre-existing pond in the locale since at least 1938 [12],

2. Enhancement $(N=8)$ : Pond existed historically and was in filled,

3. Invasive predatory species removal $(N=3)$ : Pond exists with predatory non-native species present.

The technique used to artificially construct and enhance ponds was developed following Biebighauser [29]. All construction and enhancement activities had a site plan and a stewardship agreement. The plan envisioned the size and shape of the pond, buffers, and re-vegetation if needed. The plan and agreement also guided conservation management practices such as maintaining buffers, the location of any structures (e.g., spray shed, nest box, fencing etc.), and information regarding the value and actions that support native species and habitat conservation. A preliminary on-site assessment was conducted to ensure appropriate site conditions (i.e., test hole to observe inundation and the depth of fine textured soil, such as clay and silt loam, needed to retain water). Where the substrate was permeable, an alternative design was implemented installing an 'aquatic safe' synthetic $45 \mathrm{~mL}$ ethylene propylene diene monomer (EPDM) liner coupled with a geotextile fabric pad to reduce root penetration and to absorb wildlife impact $(N=3)$.

In some sites, access to supplemental water was available through existing infrastructure. At project sites with agricultural irrigation, runoff likely contributed to pond surface water and could provide water for new plantings. Project sites with a pond liner also had accessibility to irrigation water for supplemental filling. The water management practices at each site were independently controlled by the landowner.

In six sites, a registered professional biologist was hired to assess if any species at risk might be negatively impacted by the activities. All activities were conducted in the presence of a biologist and when on private lands the owner was present to participate. Construction and enhancement activities were conducted in the fall when the ground was driest and the likelihood of disturbing wildlife was decreased. A single exception was made, where coordination with Conservation Authorities (Province of British Columbia, Report all Poachers and Polluters) permitted activities in early spring.

An experienced contractor using either a backhoe or an excavator excavated the sites for the reconstructed ponds. The general aspects of pond shape and water depth were variable and often constrained by the site geographical, physical properties, and land-use characteristics, when possible, the bank was contoured with a 10:1 slope ratio $(1 \mathrm{~m}$ of rise for every $10 \mathrm{~m}$ horizontal distance). Design considerations included species-specific priorities. This meant that sites designed to attract Great Basin spadefoots (Spea intermontana) were generally dug less than $0.6 \mathrm{~m}$ deep relying predominantly on surface run off, whereas ponds designed to attract Blotched tiger salamanders (Ambystoma mavortium) had depths as deep as $1.5 \mathrm{~m}$. The depth of ponds was based on identified key attributes of the species needed to provide the shallow areas for egg and larval development [26,27], and in the case of the deeper ponds to prevent cat tail intrusion and maintain permanent open water. The excavated material (surface vegetation and subsurface soil) was reincorporated into the banks $(N=13)$, or because of restricted land availability or a very high density of non-native invasive plants were either moved to compost on site $(N=1)$, or taken off site to the regional dump $(N=4)$. To reduce erosion and promote soil structure, in addition to reduce weed invasion [30], the exposed excavation area was seeded by hand using a winter rye as a cover crop followed by straw mulch [29].

While the construction and enhancement activities to establish ponds were completed in one to three days' effort, the invasive predatory fish (Carassius auratus, $N=1$ site) were removed using seine nets over two consecutive spring seasons (2008 and 2009) [31]. Removal of American bullfrogs (Lithobates catesbeianus) required extensive effort over eight seasons ( $N=2$ sites, 2004 to 2011; as described in [32]). 


\subsection{Species Monitoring}

From late April to mid-July, both daytime visual encounter surveys and nighttime auditory surveys were conducted at each site on two to six occasions per season using standard methods from The British Columbia Ministry of Environment Guidelines [33]. Visual encounter surveys involved searching the pond shoreline and submergent vegetation zone, in some cases using a dip net. All species observed were counted and the life stage (e.g., egg, larval, metamorphic, hatchling, adult) recorded. Auditory surveys lasted at least five (uninterrupted) minutes and were recorded using a calling index, where $0=$ no calls heard, $1=$ calling individuals can be counted, $2=$ calls of individuals are distinguishable (some calls overlap), 3 = full chorus, individuals cannot be distinguished [33]. As the detection of any occurrence was valuable, all incidental calls were also recorded. In 2007-2008, 2014 permanent ponds ( $N=4$ sites) adjacent to known Blotched tiger salamander sites were surveyed using baited (canned sardines) minnow traps fitted with flotation noodles. Commercial minnow trap dimensions were $23 \times 41 \mathrm{~cm}$ with a $3 \mathrm{~cm}$ opening on each end and constructed with $0.65 \mathrm{~mm}$ galvanized steel mesh and a spring-clip closure. Traps were set at sundown and retrieved early the following morning. All animals were released at the point of capture. Time surveys were conducted by graduate students and the author, whereas effort was often conservatively estimated for trained non-governmental organization volunteers and landowner voluntary reports, which represented about $20 \%$ of survey effort.

All procedures conducted in this research followed the Canadian Council on Animal Care [34] using approved protocols from Environment Canada (Delta, British Columbia and University of Waterloo (AUP \# 1109) Institutional Animal Care Committees; research permits were obtained from the British Columbia Ministry of Environment (\#PE06-21835; \#PE13-87949). To ensure no cross contamination of amphibian disease or transport of non-native species among sites all field equipment was disinfected with $10 \%$ bleach solution daily. To further reduce risk, sites with known American bullfrog populations had dedicated site-specific equipment.

\subsection{Terrestrial Soil Characteristics}

In 2008, terrestrial substrate suitability to enable fossorial species burrowing, represented by soil compaction, was assessed at a subsample of regional pond sites $\left(N_{\text {total }}=21\right.$ sites $)$ as a measure of upland terrestrial habitat quality. Using a handheld penetrometer (Cole Parmer \#EW-99039-00) the unit was placed upright against the substrate until the calibration mark on the piston was level with the soil; the hole's depth was then measured as an indicator of compressive strength from 0 to 4.5 tons per sq ft. Pond sites were classified as conventional orchards; e.g., use of conventional farming techniques including inputs, tilling etc. $(N=8)$-reference; e.g., native grasslands or non-grazed fields $(N=6)$; and a subsample of our constructed (project) ponds $(N=7)$ (Table 1$)$. The reference sites were selected based on the presence of known breeding amphibians, whereas the conventional sites were based on the accessibility to ponds on private lands and in some cases had breeding amphibian. The subsample of seven constructed ponds was selected from 13 possible pond sites, and was based on accessibility to surrounding areas and spatial representation of sites within the valley.

From the pond shoreline, at each cardinal direction, measurements were taken along a transect at 3 , 13,28 , and $192 \mathrm{~m}$ respectively. At each sampling point, three repeated penetrometer measurements were taken and the average recorded. A one square meter quadrat was visually estimated for the dominant cover. The type of land cover at the sampling points was recorded and included 11 quadrat classes: water, reed canary grass (Phalaris arundinacea L., Poaceae) hay field, new vineyard or recently tilled vineyard, native vegetation, native desert grasses, invasive weeds, couch grass (Elymus repens (L.) Gould, Poaceae), cement or gravel, no-till area between the fruit tree lines, and other; i.e., garbage, structure.

To compare differences between the three site classifications and with increasing distance from ponds, a repeated measures analysis of variance compared site classifications with a multiple comparison post hoc Dunnett test comparing each classification with the reference sites. A second analysis was a univariate test assessing the quadrat class (e.g., hay field), treating distance as 
independent, followed by a Tukey post hoc analysis to determine which quadrat classes are contributing to differences seen among substrate types. All statistical analyses were performed using Statistica 6.1, Statsoft, (TIBCO Software Inc., Tulsa, OK, USA) [35].

\section{Results}

Of the 21 project sites, 13 sites were constructed within the priority $500 \mathrm{~m}$ buffer areas of adjacent breeding sites (Figure 2). A variety of ephemeral and permanent ponds were designed (Table 1), with four sites within proximity and constructed or enhanced specifically for Blotched tiger salamanders (Ambystoma mavortium) (Sites \# 9, 10, 14, 17). Some sites required additional construction, most notably site \#11 that was enhanced in fall 2007; it failed to hold water and required an ethylene propylene monomer (EPDM) liner that was installed in fall 2010. Site \#19 was the only site that failed outright-it has not successfully held water since construction. Three enhancement sites that filled with water initially are becoming seasonally dry sooner and more frequently (Sites \# 4, 5, 15; Table 1).

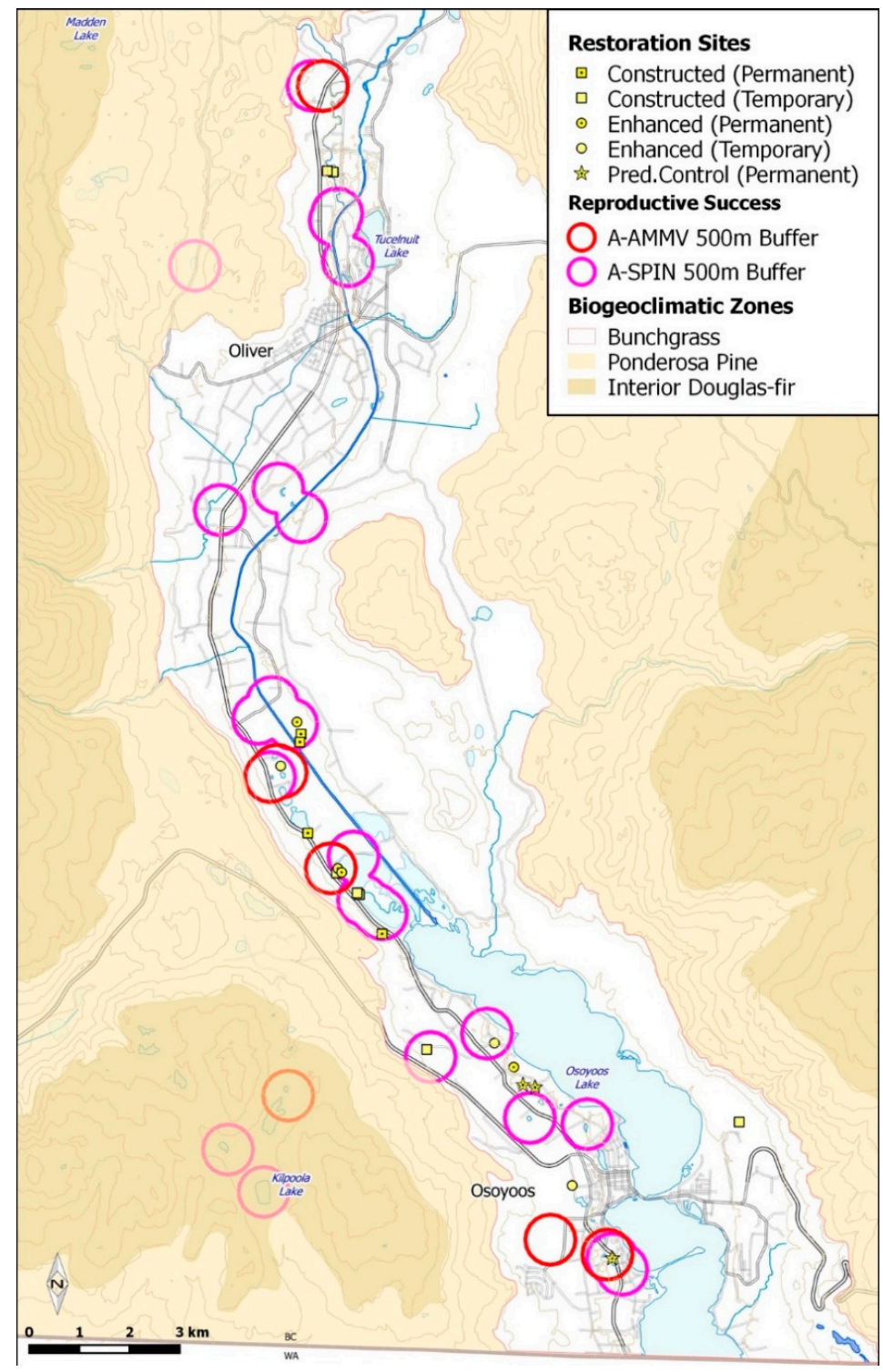

Figure 2. Location of pond habitat activities (construction $N=10$, squares, enhancement $N=8$, circles, non-native species removal $N=3$, stars) in proximity to priority known Basin spadefoot and Blotched tiger salamander breeding sites south Okanagan River Valley, British Columbia study area. Amphibian (A) species codes: A-AMMV Blotched tiger salamander, A-SPIN Great Basin spadefoot. 
Table 1. Summary of pond enhancement and construction site activities, general pond parameters, and site selection criterion, south Okanagan River Valley British Columbia, 2006-2012. Codes: NGO Non-governmental organization, GO Governmental organization.

\begin{tabular}{|c|c|c|c|c|c|c|c|c|c|c|}
\hline $\begin{array}{l}\text { Land } \\
\text { Tenure }\end{array}$ & Site \# & Year * & Activity Type & $\begin{array}{c}\text { Pond } \\
\text { Dimensions (m) }\end{array}$ & Pond Shape & $\begin{array}{l}\text { Pond Water } \\
\text { Sub-Class }\end{array}$ & $\begin{array}{l}\text { Type of Closest } \\
\text { Water Body }\end{array}$ & $\begin{array}{l}\text { Distance to } \\
\text { Nearest Water } \\
\text { Bodies (m) }\end{array}$ & $\begin{array}{l}\text { Distance to Closest } \\
\text { Known Breeding } \\
\text { Pond }{ }^{\wedge}(\mathrm{m})\end{array}$ & $\begin{array}{l}\text { Distance to } \\
\text { Highway (m) }\end{array}$ \\
\hline Private & 1 & 2006 & Enhancement & $22 \times 28$ & Half moon & Permanent & Creek & 118 & 668 & 243 \\
\hline NGO & 2 & $2006+$ & Enhancement & $20 \times 30$ & Oval & Permanent & Isolated oxbow & 35 & 498 & 973 \\
\hline NGO & 3 & $2006+$ & Constructed & $27 \times 32$ & Oval & Permanent & Isolated oxbow & 110 & 287 & 828 \\
\hline NGO & 4 & 2006 & Constructed & $6 \times 11$ & Oval & Ephemeral & Isolated oxbow & 332 & 277 & 185 \\
\hline NGO & 5 & $2006+$ & Constructed & $7 \times 14$ & Oval & Ephemeral & Isolated oxbow & 365 & 116 & 118 \\
\hline Private & 6 & 2006 & Enhancement & $14 \times 37$ & Half moon & Ephemeral & Permanent pond & 128 & 629 & 344 \\
\hline Private & 7 & 2007 & Constructed & $6 \times 8$ & Oval & Ephemeral & Oxbow & 15 & 385 & 310 \\
\hline NGO & 8 & 2007 & Constructed & $8 \times 9$ & Oval & Permanent & Oxbow & 35 & 210 & 905 \\
\hline NGO & 9 & $2007+$ & Enhancement & $17 \times 31$ & Oval & Permanent & Permanent pond & 100 & 55 & 110 \\
\hline NGO & 10 & $2007+$ & Enhancement & $25 \times 32$ & Oval & Permanent & Permanent pond & 155 & 75 & 110 \\
\hline Private & 11 & 2007 & $\begin{array}{l}\text { Enhancement; } \\
2010 \text { liner }\end{array}$ & $\begin{array}{c}7 \times 55 \\
\text { liner } 7 \times 21\end{array}$ & Teardrop & Ephemeral & Lake & 110 & 1300 & 125 \\
\hline NGO & 12 & $2007+$ & Constructed-liner & $30 \times 50$ & Square & Ephemeral & Ornamental pond & 65 & 65 & 185 \\
\hline NGO & 13 & $2007+$ & Constructed-liner & $4 \times 8$ & Oval & Ephemeral & Ornamental pond & 405 & 405 & 676 \\
\hline Private & 14 & $\begin{array}{l}2008 * \\
2009 *\end{array}$ & $\begin{array}{l}\text { Non-native Fish } \\
\text { species }\end{array}$ & $40 \times 100$ & Oval & Permanent & Permanent pond & 210 & 377 & 60 \\
\hline Private & 15 & 2009 * & Enhancement & $17 \times 19$ & Oval & Ephemeral & Ephemeral pond & 297 & 1000 & 335 \\
\hline Private & 16 & $2009 *$ & Enhancement & $50 \times 70$ & Horseshoe & Permanent & Lake & 239 & 664 & 260 \\
\hline $\mathrm{GO}$ & 17 & 2010 & Constructed & $17 \times 42$ & Teardrop & Permanent & Permanent pond & 79 & 140 & 82 \\
\hline $\mathrm{GO}$ & 18 & 2011 & Constructed & $40 \times 40$ & Oval & Permanent & Ephemeral pond & 240 & 240 & 71 \\
\hline GO & 19 & 2010 & Constructed & $32 \times 51$ & Oval & Ephemeral & Permanent pond & 75 & 840 & 25 \\
\hline Private & 20 & $\begin{array}{c}2004 \\
2011\end{array}$ & $\begin{array}{l}\text { Non-native } \\
\text { species }\end{array}$ & $62 \times 84$ & Oval & Permanent & Permanent pond & 317 & 360 & 170 \\
\hline Private & 21 & $\begin{array}{c}2004 \\
2011 \text { * }\end{array}$ & $\begin{array}{l}\text { Non-native } \\
\text { species }\end{array}$ & $76 \times 130$ & Oval & Permanent & Permanent pond & 317 & 560 & 402 \\
\hline
\end{tabular}

* Spring habitat enhancement activities, all remaining activities were conducted in the fall. + Sites assessed for terrestrial soil suitability. ^ Distance to the closest known location of an existing Great Basin spadefoot or Blotched tiger salamander breeding site. 


\subsection{Species Monitoring}

No trend was observed with the colonization or production of metamorphs among constructed versus enhanced ponds or between permanent versus ephemeral ponds (S1). While 8 of 21 ponds where not within the $500 \mathrm{~m}$ buffer, five of those sites were colonized (Site \# 1, 6, 11, 15, 16). During sampling, only two of six native amphibian species used the ponds in great numbers (Table 2). The Great Basin spadefoot was the most frequent species to colonize (18 of 21 ponds) and successfully produce metamorphic individuals (13 of 21 ponds) (S2, S3). The Pacific treefrog (Pseudacris regilla) colonized a similar number of ponds ( 15 of 21 ponds) but was less successful at producing metamorphic individuals ( 7 of 21 ponds). A third amphibian, the Columbia spotted frog (Rana luteiventris) was only observed as producing metamorphic individuals twice at one site (Site \# 1).

Table 2. Annual search effort, colonization (presence of any life stage), and metamorphic emergence of amphibian species utilizing constructed and enhanced pond sites (2007 to 2014). Excludes two records of metamorphic Columbia spotted frogs (site \# 1) presumed to have immigrated from known nearby breeding ponds.

\begin{tabular}{lccccccccc}
\hline \multicolumn{1}{c}{ Year } & $\mathbf{2 0 0 7}$ & $\mathbf{2 0 0 8}$ & $\mathbf{2 0 0 9}$ & $\mathbf{2 0 1 0}$ & $\mathbf{2 0 1 1}$ & $\mathbf{2 0 1 2}$ & $\mathbf{2 0 1 3}$ & $\mathbf{2 0 1 4}$ \\
\hline Number constructed or enhanced ponds & 6 & 14 & 16 & 21 & 21 & 21 & 21 & 21 \\
Auditory search effort $(\mathrm{h})$ & & 2.25 & 4.18 & 4.35 & 5.13 & 7.43 & 5.05 & 6.11 & 7.32 \\
Active search effort $(\mathrm{h})$ & & 4.53 & 12.33 & 10.51 & 10.13 & 9.24 & 9.58 & 8.59 & 13.44 \\
Great Basin spadefoot & colonized & 2 & 10 & 12 & 15 & 10 & 13 & 15 & 13 \\
& metamorph & 1 & 10 & 8 & 5 & 3 & 5 & 5 & 7 \\
Pacific treefrog & colonized & & 7 & 8 & 9 & 9 & 4 & 6 & 8 \\
Number sites colonized & metamorph & 1 & 0 & 4 & 3 & 2 & 2 & 2 & 3 \\
Number sites with metamorphic success & 1 & 10 & 11 & 7 & 4 & 7 & 6 & 8 \\
\hline
\end{tabular}

A maximum of 10 sites (2008) produced Great Basin spadefoot metemorphs in any given year; two sites produced metamophs annually (Site \# 12,13). The presence of both Great Basin spadefoot and Pacific treefrogs metamorphosing in the same year occurred at five sites (Site \# 2, 3, 13, 14, 16), whereas two sites had both species present but only one successfully metamorphosed in any single year (Site \# 1, 8). Six sites failed to produce metamorphs in any year, but calling adults, eggs, or tadpoles were detected (Site \# 4, 5, 7, 11, 18, 20).

While successful removal of American bullfrogs occurred at two sites (Site \# 20, 21) both sites retain non-native invasive fish (bass, Micropterus sp.) and only one site (Site \# 20) had a single adult Pacific treefrog observation. Successful removal of non-native invasive goldfish (Carassius auratus) at Site 14 resulted in rapid colonization of both frog species and successful metamorphosis in most years.

Two small shallow built ephemeral pond sites failed to hold water in any given year (Site \# 11, 15), and one larger one (Site \# 19) failed in all years.

\subsection{Substrate Characteristics}

Substrate compaction at the subsample of regional reference sites was similar to substrate compaction at our constructed ponds; whereas, substrate at conventional orchard sites (Dunnett: mean squared error $(\mathrm{MSE})=2.85$, degrees freedom $(\mathrm{df})=35$, statistical significance $p$-value $(p)=0.018$ ) was significantly more compact (Tukey: $\mathrm{F}_{(2,35)}=7.12, p=0.003$ ). Further, substrate compaction increased significantly with distance (Tukey: $\mathrm{F}_{(6,105)}=2.24, p=0.05$ ) from agricultural ponds (Figure 3). Due to the low frequency of some class observations, eight of eleven quadrate classes were used for analysis (reed canary grass, hay field, new vineyard or recently tilled vineyard, native vegetation, native desert grasses, couch grass, cement or gravel, no-till area between the fruit tree lines) (S4). Among quadrat classes, couch grass (MSE 1.83) and cement/gravel (MSE 4.76) substrates were significantly more impenetrable (Tukey: $\mathrm{F}_{(7,257)}=136.19, p<0.000$ ), compared to all other quadrat classes which were similar to each other (Dunnett: MSE 0.27 to 0.66 ). 


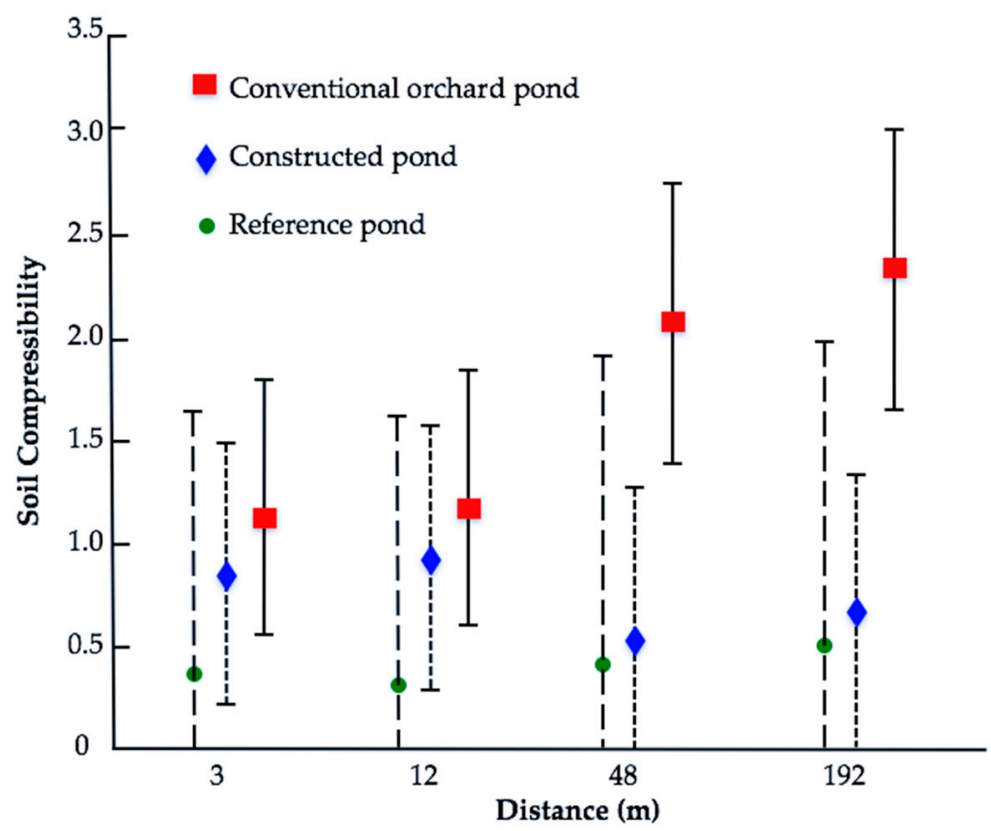

Figure 3. Soil compaction varied significantly with distance among a subsample of constructed, conventional orchards, and reference ponds with substrate compaction increasing with distance among conventional orchard and remained consistent among reference sites (Tukey: $F_{(6,105)}=2.24, p=0.05$ ). Bars denote $95 \%$ confidence interval.

\section{Discussion}

Our 'small pond' project supports our hypothesis that strategically constructed and enhanced ponds can provide breeding habitat aiding in the species at risk recovery of Great Basin spadefoot in the lower south Okanagan River Valley. While the action of constructing ponds to support the Blotched tiger salamanders (Ambystoma mavortium) remain elusive. We conducted pond monitoring ranging between two to eight years' post construction and enhancement activities. We highlight this because too many restoration projects have too few years post-construction monitoring or neglect to report challenges. Monitoring, evaluation, and adaptive enhancement efforts are recognized where project outcomes change over time. Nonetheless, we contend that our results now support a scaled-up implementation of restoration management that can be applied throughout the Okanagan River Valley and a broader recommendation that pond construction and enhancement can mitigate anthropogenic stressors in degraded landscapes for pond species. In a landscape where ponds are sparse, the anecdotal observation by landowners, local naturalists, and the authors, of a plethora of native species utilizing project ponds fuels support for continued restoration.

Our constructed and enhanced ponds ultimately doubled the availability of fishless ponds in the lower valley [8]. Just over half the enhanced and constructed ponds (12 of 21 ponds) are located on conservation lands protecting the ponds in perpetuity. However, ponds on private lands are where the greatest need exist to connect wetland mosaics. Overall, $70 \%$ of ponds were within dispersal abilities, several exceeding $500 \mathrm{~m}$, and resulted in colonization within the first two years of construction and produced metamorphic success $38 \%$ of the time. Our project increased the number of regionally known lowland Great Basin spadefoot breeding ponds from eleven to twenty-nine increasing the potential for species recovery. We have evidence of amphibian colonization at $90 \%$ of our ponds (19 of 21 ponds), with confirmed metamorphosis at $62 \%$ of ponds ( 13 of 21 ponds). Where eggs and/or tadpoles were detected, but not metamorphs, it was presumed that predation was a likely contributor. Predatory bird and snake's species were often observed depredating eggs and tadpoles at ponds. We suspect as ponds naturalize the rates of predation will decrease as refugia develop. Species response to habitat features over time has reported increased metamorphic success with vegetation cover [36]. Permanent 
ponds resulted in about twice the likelihood of metamorphic success compared to the ephemeral ponds. Ephemeral ponds with metamorphic success was likely a result of supplemental irrigation water (see below). Many variables may contribute to site occupancy or population trends; however, no clear pattern was observed between or any of the location variables. Distance to a known breeding pond was not a predictable variable, as five sites were colonized that exceeded our $500 \mathrm{~m}$ buffer. Further, the use of constructed ponds (where no previous pond existed) was just as variable as the use of enhanced ponds where wetland sites were historically present. We suspect that the lack of overall habitat availability and the narrow geographic scale contributed to the use of our project ponds. Our next steps are an analysis to examine overall regional patterns of breeding pond use and the influence of micro-habitat characteristics and landscape variables.

While the detection of adult herpetofauna indicated successful dispersal to many ponds and the presence of early life stages suggested successful mating, our measure of pond success was the production of metamorphs as an indicator of habitat quality that can support sustaining populations. Survival was not measured, but one study estimated survival from egg to metamorph in anurans to be $0.7 \%$ to $1.3 \%$ (Sahara frog species, [37]). Studies examining metamorphs at constructed ponds compared to references sites have shown variable outcomes beyond simple presence, including altered community structure, and variability in metamorphic body size depending on species [5,38]. Similarly, some authors contribute differences in metamorphic development to be due to hydrologic regimes, pond size, substrate, vegetation, and surrounding terrestrial habitats and the limited availability of species to colonize [5,14]. While not measured here, variation in similar habitat characteristics have been anecdotally observed and the limited availability of individuals to colonize is hypothesized for the Blotched tiger salamander [31].

The aim of our restoration and enhancement criteria was to increase the likelihood of colonization and connectivity between ponds. Topics of dispersal, home range, and corridor-use are only recently being explored in the northern part of Great Basin spadefoot range, where mean migratory movements are significantly longer than previously thought (range 75 to $2350 \mathrm{~m}$; [39]). If Great Basin spadefoot movement ranges are similar for our study area, then all ponds within the lower south Okanagan River Valley are bisected by highways and fragmented by multiple land uses. The number of Blotched tiger salamander breeding ponds in the lower valley are few and clustered within restrictive areas $[9,40]$. We were particularly selective in the locations of ponds that targeted restoring salamander habitat, such as direct adjacency to a known breeding site and without road barriers. It may be possible to increase the availability of suitable Blotched tiger salamander habitat within a cluster since resident salamanders have been found to stay within $150 \mathrm{~m}$ of their breeding ponds within the valley [41]. But since all lowland ponds are within $1 \mathrm{~km}$ of wetlands where a negative association has been found between the presence of tiger salamanders (Ambystoma. $t$. tigrinum) and lineal distance of paved roads [42] it is unlikely that salamander populations may be restored at a landscape level. While limited in overall regional scale, highway mitigation efforts (i.e., fencing, ecopassages) have shown success at reducing amphibian mortality within a $3.2 \mathrm{~km}$ stretch that bisects upland terrestrial from a Blotched tiger salamander breeding pond cluster and an important ephemeral wetland area [28].

A high priority when building ponds is the ability to hold water and achieving the length of pool duration required for larval development [38]; this may seem trite but improper design for such basic outcomes can doom projects. We designed some ponds to fulfill the needs of ephemeral pond breeders and some for species requiring multi-year larval development and permanent ponds. Like natural ephemeral wetlands, particularly in an arid environment, it was expected that constructed ephemeral ponds reliant on surface water would likely remain dry in some years. We expected that amphibians breeding in our ephemeral ponds may experience potential risk of larval mortality due to seasonal drought. It is not known if the mortality risk due to seasonal hydrology differs between natural and constructed ephemeral ponds. The population fluctuations of the Great Basin spadefoot rely on population growth in some, but not all years. Consequently, the failure of some ponds to become inundated with water or the failure to produce metamorphs in some years might not be critical to 
overall long term population growth and may more closely represent natural patterns. Not surprisingly, sites relying strictly on surface runoff were frequently observed dry. We hypothesized at two sites (Site \# 11,19), that a perforation in the natural clay liner during construction resulted in the failure to hold water. In the first case, a liner was installed and the pond now holds water and in some years, produces metamorphs. However, in the second case, management to mitigate water loss has yet to be taken (Site \# 19). It is possible that these sites were poorly selected or designed and it is important to acknowledge such challenges in restoration activities. Increasing hydroperiod in a natural environment is challenging, particularly constructed ephemeral ponds without supplemental water. On the other hand, dry ponds after metamorphosis have some benefit in the south Okanagan River valley and elsewhere in that it discourages successful colonization by non-native invasive species such as predatory fish or the American bullfrog, who is dependent on permanent aquatic environments. The local prevalence of intentional stocking in small ponds is pervasive and the risk of fish intrusion during flood years poses a risk to some of our permanent ponds. A long-term challenge is the maintenance of permanent ponds as fish free.

The project ponds located within agricultural lands benefited from an increase in surface water from irrigation and the availability of water infrastructure to artificially augment ponds. While augmenting ponds with water may appear to be a straightforward solution and in some cases feasible, it is neither cost effective nor a self-perpetuating system. Further, environmental and landscape ques used by the Great Basin spadefoot for stimulating movement to breeding ponds, calling, and subsequent breeding do not follow a clear pattern. The timing of Great Basin spadefoot breeding choruses and subsequent egg laying in existing agricultural ephemeral ponds have been connected to the timing of irrigation and subsequent wetland inundation, versus rain that has been observed in other regional ponds [40].

Two of our liner ponds located on the upper benches in natural habitat require regular augmentation with water to ensure metamorphic success. However, in these two cases the landowners wait till nearby choruses begin and then augment the ponds and do so until metamorphic development is completed, representing a more natural breeding chronology. While the initial intention was for ephemeral ponds to perform as natural systems, it is realized that the manipulation of water has become a recommended approach to climate change mitigation [43]. Further, our constructing permanent ponds adjacent to known Blotched tiger salamander (Ambystoma mavortium) sites did not result in any observation of colonization, which might be a lag in dispersement because of high site fidelity to natal ponds (e.g., Eastern tiger salamander, [44]) with an estimate of $20 \%$ dispersal to new ponds (e.g., California tiger salamander Ambystoma californiense, [45]).

Restoration efforts may be marginalized if only a single habitat is considered, which is a common occurrence when working with rare and specialized species. Great Basin spadefoot ecological research has primarily focused on associations with the aquatic breeding habitat [46-48]. Loss and transformation of native soils in the Okanagan River Valley [49] represent a serious issue for the maintenance of ecosystem function [50,51]. The impact of habitat modification and the availability of loose sandy soil, was significantly greater and often impenetrable around existing agricultural pond sites and sites adjacent to road ways or developed areas compared to our reference and project site ponds. The soil compaction around conventional orchard ponds was often greater than $253 \mathrm{~kg} / \mathrm{m}^{2}$, which likely impedes fossorial species movement through agricultural and urban developed lands. Intense agricultural practices (high inputs, monocrop culture, soil compaction) and urbanization are the mechanisms driving the loss and transformation of critical native desert habitat [12] at an ongoing rate that has not been quantified. Protecting the unique biodiversity of the south Okanagan River Valley will require wide scale protection of soil habitat element within a landscape management framework that incorporates all systems and spectrums of transformation [52].

The existence or provision of sandy substrates with native vegetation enhancement is an absolute necessity when restoring spadefoot habitats and corridors [33]. Our substrate results support that, at least a subsample of our constructed ponds was in habitats similar to reference sites. Our intention was to select the best possible habitat for project sites, however only 12 of 21 project sites had habitat 
with native vegetation and loose sandy soil. The remaining sites were within agricultural lands where farming practices likely contribute to a variety of stressors. Long term monitoring of regional wetlands has found agricultural ponds to be key breeding sites [9], however agricultural sites may serve as ecological traps [53] where individuals select sites with a myriad of stressors (i.e., chronic and acute contaminant exposure, rapid hydrological changes). The purpose of our soil penetrability analysis was to examine if our project site selection could provide adequate terrestrial refugia microhabitat. The soil penetrability among many of our project sites was similar to regional reference sites with known breeding populations. Due to the limitations of our sampling design, we cannot assess if there is a relationship between sites with loose sandy soil and habitat use among land-use types. A landscape analysis examining such a relationship would provide greater understanding to the degree of importance or extent which substrate restoration is needed. It can be presumed that as the sandy soil landscape is altered and compacted via urban and agricultural use, there are fewer and more sparsely distributed pockets of suitable burrowing microhabitats. In urban environments, well-drained sandy soils are being replaced with solid asphalt, grass sod, and other materials unable to provide suitable refugia for burrowing species [48]. Laboratory and field trials have established that adults cannot successfully burrow into sod, and less so in gravel [54]. Additionally, energy costs and predation exposure with increased or failed burrowing increase significantly under unsuitable substrate conditions compared with loose soils. Newly metamorphosed spadefoots (Scaphiopus h. holbrookii) were more sensitive to substrate modifications: In addition to sod and gravel, metamorphosed spadefoots could not burrow into water-saturated soils [54]. Similar experiments looking at juvenile substrate preferences found a higher degree of specificity in substrate selection required for successful burrowing [48] compared to adult spadefoots (S. h. holbrookii). As substrates in urbanized and agricultural areas of the Okanagan become increasingly impervious, the likelihood of spadefoots being excluded from these areas increases.

Amphibian restoration typically focuses on breeding habitats, however accessibility to refugia in the terrestrial zone during non-breeding periods may be critical for fossorial species. A strategy to support land conservation and management that retain and enhance native vegetation and soil systems will likely have the greatest overall benefit to an arid ecosystem. However, restoration may be augmented if spadefoots are similar to other highly terrestrial amphibian species: they may make use of constructed burrows by other species. The use of mammal burrows for refugia and tree crevasse for overwintering have been observed during telemetry studies in Great Basin Spadefoots [55] and other desert burrowing amphibian species (Scaphiopus couchii [56]). Existing burrows may allow for movement across a greater range of substrates. As such, conservation of burrowing species and burrow structures could be explored as a supporting feature for restoration sites, particularly with modified substrates

\section{Conclusions}

The availability of suitable terrestrial, aquatic, and connecting habitat corridors is fundamental to amphibian reproductive success and long-term population persistence [24,57]. Fossorial amphibians are encountering landscapes with increasingly modified habitats on all fronts: including the lack of breeding ponds and increasing threat of impervious soils. Restoration efforts require an approach that addresses the unique aspects of species ecology. But, there is a need to go beyond a single species strategy with a narrow focus to address the needs of wetland mosaics and complex ecosystems [58]. Ongoing local support and recognition for small wetland conservation needs to continue, but requires protection of identified natural aquatic and terrestrial habitat elements under policy. The economic value of natural and constructed wetlands increase in areas under anthropogenic pressure, yet biodiversity is a highly-valued service (see meta-analysis: [59]). A recent evaluation of the Okanagan River Valley wetland ecosystem provides an estimated \$314 million/year in regional natural capital and ecosystem services [60], which should place the value of restoration and conservation 
high. Both the social and ecological benefits of restoration can be significantly enhanced when spatial analysis of stressors and ecosystem services are combined [61].

Author Contributions: S.L.A. conceived, designed, implemented, collected data, and wrote the research manuscript. C.A.B. conceived and helped design this study and S.D.M. edited the manuscript.

Funding: The Habitat Stewardship Fund (Grant Contribution Agreements 2008HSP4638, 2007HSP4253, 2006HSP4277) and the Endangered Species Recovery Fund, World Wildlife Fund (Grant Contribution Agreements 2008ESRF1600, 2007ESRF1325, 2006ESRF1424), with generous contributions of land stewards and local businesses, provided funding for 17 small pond projects. Three pond constructions were funded by regional and provincial government organizations and one site was funded by a local non-government organization.

Acknowledgments: The baseline amphibian monitoring data was collected in partnership with Environment Canada (2003 to 2006) and provided the background amphibian occurrence and habitat stressor assessment to justify habitat enhancement measures. The initial Small Pond Project proponent was Ducks Unlimited Canada (2006 to 2008) followed by stewardship facilitation and the Okanagan Similkameen Stewardship Society (formerly a program administered by TLC The Land Conservancy of British Columbia). Important collaborators include both local government organizations and non-government organizations that facilitated educational programming; volunteers, Shane de Solla for statistical assistance, Randi Shulman for editing, and advisors Rob Feick and John Lewis for their constructive comments.

Conflicts of Interest: The authors declare no conflict of interest. The funders had no role in the design of the study; in the collection, analyses, or interpretation of data; in the writing of the manuscript, and in the decision to publish the results.

\section{References}

1. Stuart, S.N.; Chanson, J.S.; Cox, N.A.; Young, B.E.; Rodrigues, A.S.L.; Fishman, D.L.; Waller, R.W. Status and trends of amphibian and extinctions worldwide. Science 2004, 306, 1783-1786. [CrossRef] [PubMed]

2. Wake, D.B.; Vredenburg, V.T. Are we in the midst of the sixth mass extinction? A view from the world of amphibians. Proc. Natl. Acad. Sci. USA 2008, 105, 11466-11473. [CrossRef] [PubMed]

3. Blaustein, A.R.; Han, B.A.; Relyea, R.A.; Johnson, P.T.; Buck, J.C.; Gervasi, S.S.; Kats, L.B. The complexity of amphibian population declines: Understanding the role of cofactors in driving amphibian losses. Ann. N. Y. Acad. Sci. 2011, 1223, 108-119. [CrossRef] [PubMed]

4. Calhoun, A.J.K.; Arrigoni, J.; Brooks, R.P.; Hunter, M.L.; Richter, S.C. Creating successful vernal pools: A literature review and advice for practitioners. Wetlands 2014, 34, 1027-1038. [CrossRef]

5. Pechmann, J.H.K.; Estes, R.A.; Scott, D.E.; Gibbons, J.W. Amphibian colonization and use of ponds created for trial mitigation of wetland loss. Wetlands 2000, 21, 93-111. [CrossRef]

6. Shulse, C.D.; Semlitsch, R.D.; Trauth, K.M.; Williams, A.D. Influences of design and landscape placement parameters on amphibian abundance in constructed wetlands. Wetlands 2010, 30, 915-928. [CrossRef]

7. Lesbarrères, D.; Ashpole, S.L.; Bishop, C.A.; Blouin-Demers, G.; Brooks, R.J.; Echaubard, P.; Govindarajulu, P.; Green, D.M.; Hecnar, S.J.; Herman, T.; et al. Conservation of herpetofauna in northern landscapes: Threats and challenges from a Canadian perspective. Biol. Conserv. 2014, 170, 48-55. [CrossRef]

8. British Columbia. Statistics. Available online: http://www.bcstats.gov.bc.ca/StatisticsBySubject/ EnvironmentalStatistics.aspx. (accessed on 4 September 2016).

9. Ashpole, S.L. Restoring a wetland complex for amphibian populations, South Okanagan Valley, British Columbia, Canada (2003 to 2014). Ph.D. Thesis, University of Waterloo, Waterloo, ON, Canada, 2016.

10. Committee on the Status of Endangered Wildlife in Canada. COSEWIC Assessment and Update Status Report on the Great Basin Spadefoot Spea Intermontana in Canada; COSEWIC: Ottawa, ON, Canada, 2007. Available online: www.sararegistry.gc.ca/status/status_e.cfm (accessed on 4 September 2015).

11. Committee on the Status of Endangered Wildlife in Canada. COSEWIC Assessment and Status Report on the Tiger Salamander Ambystoma Tigrinum in Canada; COSEWIC: Hull, QC, Canada, 2011.

12. Lea, T. Historical (pre-settlement) ecosystems of the Okanagan Valley and Lower Similkameen Valley of British Columbia-Pre European contact to the present. Davidsonia 2008, 19, 3-33.

13. South Okanagan Similkameen Conservation Program. Keeping Nature in Our Future: A Biodiversity Conservation Strategy for the South Okanagan Similkameen. Available online: http:/ / www.rdosmaps.bc.ca/min_bylaws / contract_reports /CorpBd/2012/11June07/PlanningDev/2_BiodiversityStrategyExecutiveSummary2012. pdf (accessed on 25 May 2012). 
14. Knutson, M.G.; Richardson, W.B.; Reineke, D.M.; Gray, B.R.; Parmelee, J.R.; Wick, S.E. Agricultural ponds support amphibian populations. Ecol. Appl. 2004, 14, 669-684. [CrossRef]

15. MacArthur, R.H.; Wilson, E.O. The Theory of Island Biogeography; Princeton University Press: Princeton, NJ, USA, 1967.

16. Diamond, J.M. The Island Dilemma: Lessons of modern biogeographic studies for the design of natural reserves. Biol. Conserv. 1975, 7, 129-146. [CrossRef]

17. Levins, R. Some demographic and genetic consequences of environmental heterogeneity for biological control. Bull. Entomol. Soc. Am. 1969, 15, 237-240. [CrossRef]

18. Sutter, G.; Francisco, R. Vernal pool creation in the Sacramento Valley: A review of issues surrounding its role as a conservation tool. In Ecology, Conservation, and Management of Vernal Pool Ecosystems, Proceedings from 1996 Conference; Witham, C.W., Bauder, E.T., Belk, D., Ferren, W.R., Jr., Ornduff, R., Eds.; California Native Plant Society: Sacramento, CA, USA, 1998; pp. 190-194.

19. Scheffers, B.R.; Paszkowski, C.A. Amphibians use of urban storm wetlands: The role of natural habitat features. Landsc. Urban Plan. 2013, 113, 139-149. [CrossRef]

20. Brown, D.J.; Street, G.M.; Nairn, R.W.; Forstner, M.R. A place to call home: Amphibian use of created and restored wetlands. Int. J. Ecol. 2012, 2012, 989872. [CrossRef]

21. Porej, D.; Hetherington, T.E. Designing wetlands for amphibians: The importance of predatory fish and shallow littoral zones in structuring of amphibian communities. Wetl. Ecol. Manag. 2005, 13, 445-455. [CrossRef]

22. Lehtinen, R.M.; Galatowitsch, S.M. Colonization of restored wetlands by amphibians in Minnesota. Am. Midl. Nat. 2001, 145, 388-396. [CrossRef]

23. Petranka, J.W.; Holbrook, C.T. Wetland restoration for amphibians: Should local sites be designed to support metapopulations or patchy populations? Restor. Ecol. 2006, 14, 404-411. [CrossRef]

24. Semlitsch, R.D. Principles for management of aquatic-breeding amphibians. J. Wildl. Manag. 2000, 64, 615-631. [CrossRef]

25. Semlitsch, R.D.; Brodie, J.R. Biological criteria for buffer zones around wetlands and riparian habitats for amphibians and reptiles. Conserv. Biol. 2003, 17, 1219-1228. [CrossRef]

26. Environment and Climate Change Canada. Recovery Strategy for the Great Basin Spadefoot (Spea intermontana) in Canada [Proposed]; Species at Risk Act Recovery Strategy Series; Environment and Climate Change Canada: Ottawa, ON, Canada, 2017.

27. Environment and Climate Change Canada. Recovery Strategy for the Tiger Salamander (Ambystoma tigrinum) Southern Mountain Population in Canada; Species at Risk Act Recovery Strategy Series; Environment and Climate Change Canada: Ottawa, ON, Canada, 2017.

28. Crosby, J. Amphibian Occurrence on South Okanagan Roadways (2010-2012): Investigating Movement Patterns, Crossing Hotspots, \& Roadkill Mitigation Structure Use at the Landscape Scale. Master's Thesis, University of Waterloo, Waterloo, ON, Canada, 2014.

29. Biebighauser, T.R. Guide to Creating Vernal Ponds; USDA Forest Service, United States Department of Agriculture: Washington, DC, USA, 2003.

30. Moncada, K.M.; Sheaffer, C.C. Chapter 13: Tools for Managing Pest and Environmental Risks to Organic Crops in The Upper Midwest. In Organic Risk Management Handbook; University of Minnesota: Minneapolis, MN, USA, 2010; Available online: http:/ / www.organicriskmanagement.umn.edu/default.htm (accessed on 31 December 2014).

31. Ashpole, S.L.; Bishop, C.A.; Elliott, J.E. Unexplained die-off of larval tiger salamanders (Ambystoma tigrinum) in an agricultural pond in the South Okanagan Valley, British Columbia, Canada. Northwest. Nat. 2011, 92, 221-224. [CrossRef]

32. Lukey, N.A.; Cunnington, D.; Ashpole, S.L.; Murphy, S.D.; Govindarajulu, P.P. Where Do We Go from Here? Long-Term, Adaptive Management of Invasive American Bullfrogs (Lithobates catesbeianus) in the South Okanagan Valley, British Columbia, August 2012; World Congress of Herpetology: Vancouver, BC, Canada, 2012.

33. British Columbia Ministry of Environment. Guidelines for Amphibian and Reptile Conservation during Urban and Rural Land Development in British Columbia; B.C. Ministry of Environment: Victoria, BC, Canada, 2014.

34. Olfert, E.D.; Cross, B.M.; McWilliam, A.A. (Eds.) Guide to the Care and Use of Experimental Animals; Canadian Council on Animal Care: Ottawa, ON, Canada, 1993; Volume 1, No. 2.

35. StatSoft, Inc. Statistica for Windows [Computer Program Manual]; TIBCO Software Inc.: Tulsa, OK, USA, 2003. 
36. Shulse, C.D.; Semlitsch, R.D.; Trauth, K.M.; Gardner, J.E. Testing wetland features to increase amphibian reproductive success and species richness for mitigation and restoration. Ecol. Appl. 2012, 22, 1675-1688. [CrossRef] [PubMed]

37. Bellakhal, M.; Neveu, A.; Aleya, L. Artificial wetlands as a solution to the decline in the frog population: Estimation of their suitability through the study of population dynamics of Sahara Frogs in hill lakes. Ecol. Eng. 2014, 63, 114-121. [CrossRef]

38. Morey, S.R. Pool duration influence age and body mass at metamorphosis in the Western Spadefoot toad: Implications for vernal pool conservation. In Ecology, Conservation, and Management of Vernal Pool Ecosystems, Proceedings from 1996 Conference; Witham, C.W., Bauder, E.T., Belk, D., Ferren, W.R., Jr., Ornduff, R., Eds.; California Native Plant Society: Sacramento, CA, USA, 1998.

39. Richardson, J.S.; Oaten, D. Critical Breeding, Foraging, and Overwintering Habitats of Great Basin Spadefoot Toads (Spea intermontana) and Western Toads (Anaxyrus boreas) within Grassland Ecosystems; Final Report; Canadian Wildlife Federation Kanata: Ottawa, ON, Canada, 2013.

40. Ashpole, S.L.; Bishop, C.A.; Elliott, J.E. Use of anthropogenic breeding sites and clutch size in the Great Basin Spadefoot (Spea intermontana), South Okanagan Valley, British Columbia. Canada. Northwest. Nat. 2014, 95, 35-40. [CrossRef]

41. Richardson, J.S.; Klenner, W.; Shatford, J. The tiger salamander in British Columbia: An amphibian in an endangered desert environment. In Proceedings of the Conference on the Biology and Management of Species and Habitats at Risk, Kamloops, BC, Canada, 15-19 February 1999; Darling, L.M., Ed.; University College of the Cariboo: Kamloops, BC, Canada, 2000; pp. 407-412.

42. Porej, D.; Micacchion, M.; Hetherington, T.E. Core terrestrial habitat for conservation of local populations of salamanders and wood frogs in agricultural landscapes. Biol. Conserv. 2004, 120, 399-409. [CrossRef]

43. Shoo, L.P.; Olson, D.H.; McMenamin, S.K.; Murray, K.A.; Van Sluys, M.; Donnelly, M.A.; Stratford, D.; Terhivuo, J.; Merino-Viteri, A.; Herbert, S.M.; et al. Engineering a future for amphibians under climate change. J. Appl. Ecol. 2011, 48, 487-492. [CrossRef]

44. Ngo, A.; MCKay, V.L.; Murphy, R.W. Recovery Strategy for Tiger Salamander (Ambystoma tigrinum) (Great Lakes Population) in Canada [Proposed]; Species at Risk Act Recovery Strategy Series; Parks Canada Agency: Ottawa, ON, Canada, 2009.

45. Trenham, P.C.; Koenig, W.D.; Shaffer, H.B. Spatially autocorrelated demography and interpond dispersal in the salamander Ambystoma californiense. Ecology 2001, 82, 3519-3530. [CrossRef]

46. Greenberg, C.H.; Tanner, G.W. Breeding pond selection and movement patterns by eastern spadefoot toads (Scaphiopus holbrookii) in relation to weather and edaphic conditions. J. Herpetol. 2004, 38, 569-577. [CrossRef]

47. Nyström, P.; Hansson, J.; Månsson, J.; Sundstedt, M.; Reslow, C.; Broström, A. A documented amphibian decline over 40 years: Possible causes and implications for species recovery. Biol. Conserv. 2007, 138, 399-411. [CrossRef]

48. Baughman, B.; Todd, B.D. Role of substrate cues in habitat selection by recently metamorphosed Bufo terrestris and Scaphiopus holbrookii. J. Herpetol. 2007, 41, 154-157. [CrossRef]

49. Iverson, K.; Curran, D.; Fleming, T.; Haney, A. Sensitive Ecosystems Inventory-Okanagan Valley: Vernon to Osoyoos, 2000-2007. Methods, Ecological Descriptions, Results and Conservation Tools; Technical Report Series No. 495; Canadian Wildlife Service, Pacific and Yukon Region: Delta, BC, Canada, 2008.

50. Gray, M.J.; Smith, L.M.; Brenes, R. Effects of agriculture cultivation on demographics of Southern high plains amphibians. Conserv. Biol. 2004, 18, 1368-1377. [CrossRef]

51. Carisio, L.; Sacchi, R.; Seglie, D.; Sindaco, R. Habitat selection in the fossorial toad Pelobates fuscus insbricus (Amphibia: Pelobatidae). Acta Herpetol. 2014, 9, 51-59.

52. Hobbs, R.J. Setting effective and realistic restoration goals: Key direction for research. Restor. Ecol. 2007, 15, 354-357. [CrossRef]

53. Janin, A.; Lena, J.-P.; Deblois, S.; Joly, P. Use of stress-hormone levels and habitat selection to assess functional connectivity of a landscape for an amphibian. Conserv. Biol. 2012, 26, 923-931. [CrossRef] [PubMed]

54. Jansen, K.P.; Summers, A.P.; Delis, P.R. Spadefoot toads (Scaphiopus holbrookii holbrookii) in an urban landscape: Effects of nonnatural substrates on burrowing in adults and juveniles. J. Herpetol. 2001, 35, 141-145. [CrossRef]

55. Garner, J.L. Movement and Habitat-Use of the Great Basin Spadefoot (Spea intermontana) at Its Northern Range Limit. Master's Thesis, Thompson Rivers University, Kamloops, BC, Canada, 2012; pp. 1-8. 
56. Newman, R.A.; Dunham, A.E. Size at metamorphosis and water loss in a desert anuran (Scaphiopus couchii). Copeia 1994, 1994, 372-381. [CrossRef]

57. Roe, J.H.; Georges, A. Heterogeneous wetlands complexes, buffer zones, and travel corridors: Landscape management for freshwater reptiles. Biol. Conserv. 2007, 135, 67-76. [CrossRef]

58. Lindenmayer, D.; Hobbs, R.J.; Montague-Drake, R.; Alexandra, J.; Bennett, A.; Burgman, M.; Cale, P.; Calhoun, A.; Cramer, V.; Cullen, P.; et al. A checklist for ecological management of landscapes for conservation. Ecol. Lett. 2008, 11, 78-91. [CrossRef] [PubMed]

59. Ghermandi, A.; Van Den Bergh, J.C.; Brander, L.M.; de Groot, H.L.; Nunes, P.A. Values of natural and human-made wetlands: A meta-analysis. Water Resour. Res. 2010, 46, W12516. [CrossRef]

60. Parrott, L.; Kyle, C. The Value of Natural Capital in the Okanagan. Okanagan Institute for Biodiversity, Resilience, and Ecosystem Services (BRAES); The University of British Columbia: Kelowna, BC, Canada, 2014.

61. Allan, D.J.; McIntyre, P.B.; Smith, S.D.P.; Halpern, B.S.; Boyer, G.L.; Buchsbaum, A.; Burton, G.A., Jr.; Campbell, L.M.; Chadderton, W.L.; Ciborowski, J.J.H.; et al. Joint analysis of stressors and ecosystem services to enhance restoration effectiveness. Proc. Natl. Acad. Sci. USA 2013, 110, 327-377. [CrossRef] [PubMed]

(C) 2018 by the authors. Licensee MDPI, Basel, Switzerland. This article is an open access article distributed under the terms and conditions of the Creative Commons Attribution (CC BY) license (http:/ / creativecommons.org/licenses/by/4.0/). 